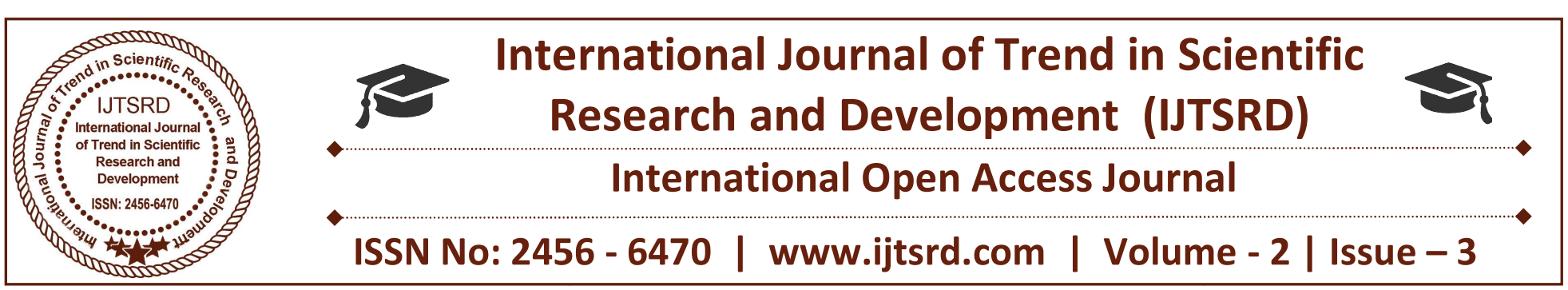

\title{
Critical Thinking for Global Peace: A key for Sustainable Development
}

\author{
Ms. Kuldeep Kaur \\ Research Scholar, Department of Education, \\ University of Allahabad, Allahabad, Uttar Pradesh, India
}

\section{ABSTRACT}

This is the age of science and technology. In today's digital era, where wide information is readily accessible, individuals need to be taught how to think critically for themselves. The world has been facing a wide range of intellectual challenges to maintain global peace. Scholars and teachers have explored them in the past too. Yet, in today's world with the advent of new technologies, staying detached is not an option. In this way, not only they have to seek solutions to the pressing issues around them but they also need to be mindful of parochial explanations of the same issues. This reflects the path to a tolerant future. Critical thinking skills are the cornerstone for global peace and sustainable development, which can be understand as an integral part of quality education, inherent in the concept of lifelong learning. Embarking on the path of sustainable development requires a profound transformation of how we think and act. Therefore, critical thinking is crucial for the achievement of global peace and sustainable development. This study presents review of literature on the importance of critical thinking for global peace. Finally, it proposes framework to foster the critical thinking abilities of students and some suggestions are made about the development of critical thinking skills.

Keywords: Critical Thinking, Global peace, Sustainable Development

"We are what our thoughts have made us; so take care about what you think.

Words are secondary. Thoughts live; they travel far."

- Swami Vivekananda

\section{INTRODUCTION}

We stand at a critical moment in Earth's history, a time when humanity must choose its future. 'As the world becomes increasingly interdependent and fragile, the future at once holds great peril and great promise' (The Earth Charter Initiative, 2000). As the quote describes, there seems to be an urgent need for making decisions that ensure a peaceful and sustainable future. In the contemporary world, there are several crises that are complex and interconnected often concerning the whole globe (Orr, 2004). They are so severe that Orr (2004) discussed about a "planetary emergency" that education needs to respond to. Hofman (2015) stated that many researchers seem to agree that sustainable development and a sustainable future need a change of people's behaviour and therefore, education for sustainable development is crucial. They require the knowledge, skills, values and attitudes that empower them to contribute to sustainable development. Education, therefore, is crucial for the achievement of sustainable development. The recent well-established approach of education for sustainable development empowers learners to take informed decisions and responsible actions for environmental integrity, economic viability and a just society for present and future generations. It requires the empowerment of individuals by reflecting on their own actions, taking into account their current and future social, cultural, economic and environmental impacts, from a local and a global perspective. Individuals should also be emancipate to act in complex situations in a sustainable manner, which may require them to strike out in new directions and to participate in sociopolitical processes, moving their societies towards 
global peace which results in sustainable development.

Sustainable development has to understand as an integral part of quality education, inherent in the concept of lifelong learning. All educational institutions from preschool to tertiary education in non-formal and informal education should consider it their responsibility to deal intensively with matters of sustainable development and to foster the development of sustainability competencies. They require holistic and transformational education that addresses learning content and outcomes, pedagogy and the learning environment. Thus, sustainable development does not only integrate contents such as climate change, poverty and sustainable consumption into the curriculum; it also creates interactive, learnercentred teaching and learning settings. It needs a shift from teaching to learning. It asks for an actionoriented, transformative pedagogy which supports self-directed learning, participation and collaboration, problem-orientation, inter and trans-disciplinarity and the linking of formal and informal learning. Only such pedagogical approaches make possible the development of the key competencies needed for promoting sustainable development.

\section{CRITICAL THINKING}

The roots of critical thinking can be detected in the 'Socratic Method' when 2,500 years ago Socrates established a method of regularizing the way that we pose questions. Later, the concepts and language for critical thinking were established in Bloom's taxonomy compiled in 1956. The taxonomy is hierarchical where each level is subsumed by the higher levels (Forehand, 2005). Critical thinking is purposeful, reasoned and goal-directed skill. It is the kind of thinking involved in solving problems, formulating inferences, calculating likelihoods and making decisions (Halpern, 1999). Thus, critical thinking involves the use of cognitive skills that increase the probability of a desirable outcome. As to the cognitive skills, the experts include as being at the very core of critical thinking: interpretation, analysis, evaluation, inference, explanation, and self regulation (Facione, 2011). Mertes (1991) defined critical thinking as a conscious and deliberate process used to interpret or evaluate information and experiences with a set of reflective attitudes and abilities that guide thoughtful beliefs and actions. McPeck (as cited Garret, 2009) defined critical thinking as the propensity and skill to engage in an activity with reflective skepticism. It represents high-order thinking skills. Robert Sternberg (1985) proposed critical thinking as the mental processes, strategies and representations people use to solve problems, make decisions and learn new concepts. It leads a person towards adequate solution of problems. Barbara Warnick and Edward Inch (1994) defined critical thinking as the ability to investigate a problem, a question or a state of affairs and ability that involves all the available information referring to the particular area.

Lipman (1995) stated that such a self-correcting thinking relies upon criteria leads to judgments and decisions and the learner may also apply it in environments other than that of the school. Diane Halpem (1996) takes the view that critical thinking has to do with the use of cognitive abilities that have enhanced possibilities of producing a positive result. It is a reflective thought that can be justified and is used in resolving problems, drawing conclusions, estimating probabilities and taking decisions. The central element of critical thinking is the capacity to evaluate both processes and solutions. According to Yildirm and Şensoy (2011), individuals who can think critically in their life are individuals who have critical thinking skills and critical thinking disposition. It is also defined as the ability to analyze facts, generate and organize ideas, defend opinions, make comparisons, draw inferences, evaluate arguments and solve problems (Chance as cited in Huitt, 1998). Robert J. Sternberg (as cited in Pogonowski, 1987) stated that critical thinking comprises the mental processes, strategies and representations people use to solve problems, make decisions, and learn new concepts.

Although the above definitions are close to each other, a great number of other definitions made are seen during review of literature. That is because various definitions of critical thinking are a result of how broadly or narrowly the construction of critical thinking is viewed (Field, 1997). In fact, classifying learning objectives and systematizing learning in a hierarchical way in education is not a new issue. Halpern (1997) stated that when we think critically, we are evaluating the outcomes of our thought processes. The evolution of this human thinking process has come to be known as cognitive process instruction and the goal is to understand how knowledge, cognitive processes and mechanisms can improve. It is one of the most important issues for instructors and researchers that what enhances critical 
thinking and how this skill can be developed. Another essential point is how critical thinking can nurture creativity in educational environment with new ideas and concepts.

\section{CRITICAL THINKING AND GLOBAL PEACE}

Critical thinking acts as a key element for reconciliation and global peace. It contributes to peace-building by enabling people to question the ideologies and narratives. Such questioning can lead to a greater understanding of conflict, a necessary precondition for the mutual trust that is required for eventual peace. Review of literature revealed that in some systems of formal education, the portrayal of one group as the perpetrators of violence and the other group as the victims impedes reconciliation. Bar-Tal and Rosen (2009) stated that a nation's collective memory often caters to this prejudicial dichotomy, as each group sees themselves as the victims. This makes reconciliation a distant utopian fantasy. They believed that peace education programs are a potential solution to this issue, but argued that these programs must incorporate critical thinking and challenge common assumptions in order for reconciliation and eventually, peace to exist.

In such a way, developing a greater understanding of the other does not signify a rejection of one's own identity; on the contrary, it can lead to a more nuanced understanding of oneself. Education has the potential to play a significant role in peace-building by imparting the knowledge and skills, especially critical thinking skills that are necessary to question and build understanding, from which peace might grow. Thus, the process of learning must enjoy conditions of freedom and values which allow critical thinking to flourish.

Critical thinking skills offer people the cognitive skills to anticipate and participate in change rather than become victims of it. If social development is the objective and expansion is about change then young adults need an education that teaches them how to change, not an education that merely teaches them how to "fit in" the existing social structures. Apart from contributing with technical skills, each of us needs to develop and apply critical thinking skills. Therefore, critical thinking skills are the cornerstone of global peace. As it provides liberal education which is one of that attempts to entitle individuals and prepare them to deal with complexity, diversity and change. It does so by developing a strong sense of social responsibility, as well as vigorous and transferable intellectual and practical skills such as communication, analytical and problem-solving skills. It enhances a demonstrated ability to apply knowledge and skills in real-world settings. We apply our critical thinking skills by questioning the status quo - that is to question the way things are. We ask Are the 'facts' true? And Is it morally right? We examine our ideas about ourselves and our ideas about ourselves inside our society.

Hence, critical thinkers understand both the opportunity and the responsibility to participate in the affairs of society. They are leaders, not followers. They lead by questioning the status quo and by daring to stand out from the rest of the crowd. Critical thinkers refuse to fall victim to logically fallacious arguments based on appeals to tradition or popularity. They combat the human tendency to be egocentric or ethnocentric - both of which are subjective and while they do help us define our personal identity at their extreme. They lead to feelings of superiority over others. Rooted in the understanding that all people are equal, a critical thinker question the social arrangements which result in some groups, the marginalized, being deprived of not only physical well-being but also the ability to make informed choices about their own futures. A critical thinker begins the process, not by looking to find fault with or blame other societies or others within their own society, but rather they look inward, at themselves. Such reflective thinkers comprehend that positive change starts from within that leads to development in sustainable manner.

\section{CONCLUSION}

Education can and must contribute to a new vision of sustainable global development (UNESCO, 2015). Embarking on the path of global peace requires a profound transformation of how we think and act. To create a more sustainable world and to engage with sustainability-related issues, individuals must become sustainability change-makers. They require the knowledge, skills, values and attitudes that empower them to contribute for sustainable development. Therefore, education is crucial for the achievement of such objectives. However, not all kinds of education support sustainable development. Education that promotes economic growth alone may lead to an increase in unsustainable consumption patterns. Thus, educators play a vital role in a society because they can use curriculum to challenge students to critically analyze their circumstances, effectively engendering 
reflection, which can lead to collective action. Sustainability for global peace aims at developing competencies that empower individuals to reflect on their own actions, taking into account their current and future social, cultural, economic and environmental impacts, from a local and a global perspective. Individuals should also be empowered to act in complex situations in a sustainable manner, which may require them to strike out in new directions and to participate in socio-political processes, moving their societies towards sustainable development. Thus, it should be taken into consideration in any educational institutions to tackle the social and cultural phenomena, which have led to the current state of the world. Development of critical thinking skills help individuals to understand complex and interconnected issues and seek solutions to them. Hence, supporting action competence i.e. critical thinking skills empowers individuals to feel a sense of freedom and being capable of contributing to local and global issues.

"You have power over your mind - not outside events. Realize this and you will find strength."

\section{-- Marcus Aurelius}

\section{REFERENCES}

1) AACU (Association of American Colleges \& Universities). What is a $21 \mathrm{st}$ century liberal education? Retrieved from: https://www.aacu.org/leap/what-is-a-liberaleducation

2) Bar-Tal, D. and Rosen, Y. (2009). Peace Education in Societies Involved in Intractable Conflicts: Direct and Indirect Models. Review of Educational Research, 79 (2), 557-575.

3) Bertschy, F., Künzli, C. and Lehmann, M. (2013). Teachers' Competencies for the Implementation of Educational Offers in the Field of Education for Sustainable Development. Sustainability, 5 (12), 5067-5080.

4) Boss, Judith A. (2010). Think: Critical thinking and logic skills for everyday life. New York: McGraw-Hill.

5) Facione, P. A. (2011). Critical thinking: What it is and why it counts. Millbrae: Measured Reasonsand The California Academic Press.

6) Fisher, A. (2001). Critical thinking: An introduction. Cambridge: Cambridge University Press.

7) Forehand, M. (2005). Bloom's taxonomy: Original and revised.. In M. Orey (Ed.), Emerging perspectives on learning, teaching, and technology. Garret, M. L. (2009). An examination of critical thinking skills in the school choral rehearsal. Unpublished doctoral dissertation. Florida State University.

8) Godemann, J. 2006. Promotion of interdisciplinary competence as a challenge for higher education. Journal of Social Science Education, 5 (2), 51-61.

9) Halpern, D. F. (1999). Teaching for critical thinking: helping collage students develop the skills and dispositions of a critical thinker. New Directions for Teaching and Learning. 80, Winter, 69-74.

10) Huitt, W. (1998). Critical thinking: An overview. Educational Psychology Interactive. Valdosta, GA: Valdosta State University.

11) Lipman, M. (1991). Thinking in Education. Cambridge: Cambridge University Press.

12) Mertes, L. (1991). Thinking and writing. Middle School Journal, 22, 24-25.

13) Paul, R.W. (1984). Teaching critical thinking in the "strong" sense: A focus on self-deception, worldviews, and a dialectical mode of analysis.Informal Logic, 2-7.

14) Paul, R. W.(1985). Bloom's taxonomy and critical thinking instruction, Educational Leadership Association for Supervision \& Curriculum Development. 42, 36-39.

15) Pogonowski, L. (1987). Developing skills in critical thinking and problem solving. Music Educators Journal, 73 (6), 37-41.

16) Rauch, F., Steiner, R. (2013). Competences for education for sustainable development in teacher education. CEPS Journal, 3 (1), 9-24.

17) Slavik, S. (1993). The Relationship between Cognitive Development and Teaching Methodologies in Art Education. Unpublished Doctoral Dissertation. Florida: Florida State University.

18) Sternberg, R. (1985). Critical Thinking: Its Nature, Measurement, and improvement. In F. R. Link (ed.). Essays on the Intellect, Alexandria, Va.: Association for Supervision and Curriculum Development.

19) Woodford, P. (1996). Developing critical thinkers. Music Educators Journal, 83 (1), 27-32.

20) Young, Nigel J. (2010). The Oxford International Encyclopedia of Peace Volume 2, Oxford: Oxford University Press. 